Zeszyty Naukowe Szkoły Głównej Gospodarstwa Wiejskiego w Warszawie

Problemy Rolnictwa Światowego tom 18 (XXXIII), zeszyt 4, 2018: 333-344

DOI: 10.22630/PRS.2018.18.4.123

Katarzyna Lukasiewicz ${ }^{1}$

Szkoła Główna Gospodarstwa Wiejskiego w Warszawie

\title{
Przyjazdy turystów zagranicznych do Polski oraz ich wydatki w latach 2014-2017 - charakterystyka i perspektywy rozwoju
}

\section{Arrivals of Foreign Tourists to Poland and Their Expenses in 2014-2017; Characteristics and Development Perspectives}

\begin{abstract}
Synopsis. Turyści zagraniczni bardzo chętnie wybierają Polskę jako cel swojej podróży. Celem artykułu jest zaprezentowanie charakterystyki przyjazdów turystów zagranicznych do Polski z uwzględnieniem ich wydatków. Wykorzystując dane pochodzące z Ministerstwa Sportu i Turystyki, Głównego Urzędu Statystycznego oraz Narodowego Banku Polskiego przedstawiono liczbę i cele przyjazdów, długość pobytu oraz wykorzystywaną bazę noclegową. W dalszej części opracowania przedstawiono zróżnicowanie wydatków turystów zagranicznych $\mathrm{w}$ Polsce $\mathrm{z}$ uwzględnieniem przeciętnych wydatków na osobe oraz na dzień pobytu. Zaprezentowano również analizę SWOT, która określa siły i słabości turystyki przyjazdowej oraz szanse i zagrożenia związane z jej rozwojem. Z przeprowadzonej analizy wynika, że przyjazdy turystów zagranicznych wzrosły w 2017 roku o 14,1\% w porównaniu do roku 2014. Największe wydatki na osobę wśród turystów zagranicznych odnotowano w przypadku turystów z krajów zamorskich, Skandynawii oraz Niemiec. Najmniej zaś wydali turyści zagraniczni z Czeskiej Republiki, Słowacji, czy Białorusi. W ramach przedstawionej analizy SWOT można stwierdzić, iż szanse rozwoju turystyki przyjazdowej do Polski opierają się głównie na takich czynnikach jak m.in.: położenie, różnorodność, coraz wyższa jakość usług, pozytywne wrażenia wracających z Polski, czy wykorzystanie marek miast (Warszawa, Kraków, Wrocław, Gdańsk).
\end{abstract}

Słowa kluczowe: przyjazd, turystyka, Polska, perspektywy

\begin{abstract}
Foreign tourists are eager to choose Poland as their destination. The aim of the article is to present the characteristics of arrivals of foreign tourists to Poland, including their expenses. Using the data from the Ministry of Sport and Tourism, the Central Statistical Office and the National Bank of Poland, the number and purposes of arrivals, length of stay and the accommodation base used were presented. The further part of the study presents the diversification of expenses of foreign tourists in Poland, taking into account the average expenditure per person and per day of stay. A SWOT analysis was also presented, which defines the strength and weakness of inbound tourism as well as the opportunities and threats associated with its development. The analysis shows that arrivals of foreign tourists increased in 2017 by $14.1 \%$ compared to 2014 . The highest expenditure per person among foreign tourists was recorded in the case of tourists from overseas countries, Scandinavia and Germany. Foreign tourists from the Czech Republic, Slovakia and Belarus issued the least. As part of the SWOT analysis presented, it can be stated that the chances of developing incoming tourism to Poland are mainly based on such factors as: location, diversity, increasingly higher quality of services, positive impressions coming back from Poland, or the use of city brands (Warsaw, Krakow, Wrocław, Gdańsk).
\end{abstract}

Key words: arrival, tourism, Poland, perspective

JEL Classification: Z32

${ }^{1}$ dr inż., Katedra Ekonomiki i Organizacji Przedsiębiorstw, Wydział Nauk Ekonomicznych SGGW w Warszawie, ul. Nowoursynowska 166,02-787 Warszawa, e-mail: katarzyna_lukasiewicz@sggw.pl; https://orcid.org/0000-0001-9715-3756 


\section{K. Eukasiewicz}

\section{Wprowadzenie}

Pojęcie „turystyka” zmieniało się na przestrzeni lat. Gaworecki uważa, że współcześnie zjawisko turystyki można rozpatrywać w różnych aspektach, co w konsekwencji powoduje, iż w rozmaitych definicjach akcentuje się różne jego cechy. (Gaworecki, 2013). Warto przytoczyć tutaj również pojęcie turystyki międzynarodowej, które może być wyjaśnione na wiele sposobów (Dąbrowska, 2011):

- różne państwa mają różne zasoby środowiskowe; turyści kierują się do państw posiadających specyficzny klimat lub warunki naturalne, których brakuje w kraju emisji (kraju pochodzenia turysty);

- popyt turystyczny kieruje się różnymi gustami, upodobaniami, modą;

- zgodnie z zasadą podziału pracy każde państwo specjalizuje się w produkcji usług turystycznych zgodnie $\mathrm{z}$ jego zasobami. Implikuje to produkcję po najniższych kosztach;

- zgodnie z modelem Heckshera-Olina każde państwo specjalizuje się w produkcji usług turystycznych zgodnie z zasobami środków produkcji. Bezpośrednia produkcja usług turystycznych nie wymaga wysoko wykwalifikowanej siły roboczej, czego wymaga natomiast jej działalność organizacyjna;

Globalnie turystykę można traktować jako sektor bardzo ważny biorąc pod uwage korzyści dla gospodarki. Turystyka pełni w niej przede wszystkim funkcje makroekonomiczne i może stymulować rozwój społeczno-gospodarczy obszarów recepcji turystycznej, a w konsekwencji gospodarki kraju przez (Balińska i in., 2014):

- tworzenie wartości dodanej, przez co wpływa na wzrost produkty krajowego brutto;

- zwiększenie wpływów dewizowych uzyskiwanych z obsługi ruchu turystycznego;

- stymulowanie rozwoju przedsiębiorczości i infrastruktury;

- tworzenie nowych miejsc pracy i zwiększenie dochodów ludności regionów turystycznych;

- zwiększanie przychodów firm obsługujących turystów oraz sprzyjanie przedsiębiorczości oraz innowacjom;

- kształtowanie dochodów budżetowych samorządów lokalnych.

Turystyka międzynarodowa jest źródłem przychodów dewizowych. W roku 2016 suma wpływów z tytułu turystyki wyniosła $1107 \mathrm{mln}$ Euro. Największy udział w przychodach z turystyki posiadała Europa (37\%). Na kolejnej pozycji znalazła się Azja i Oceania (30\%) (por. rys. 1). 


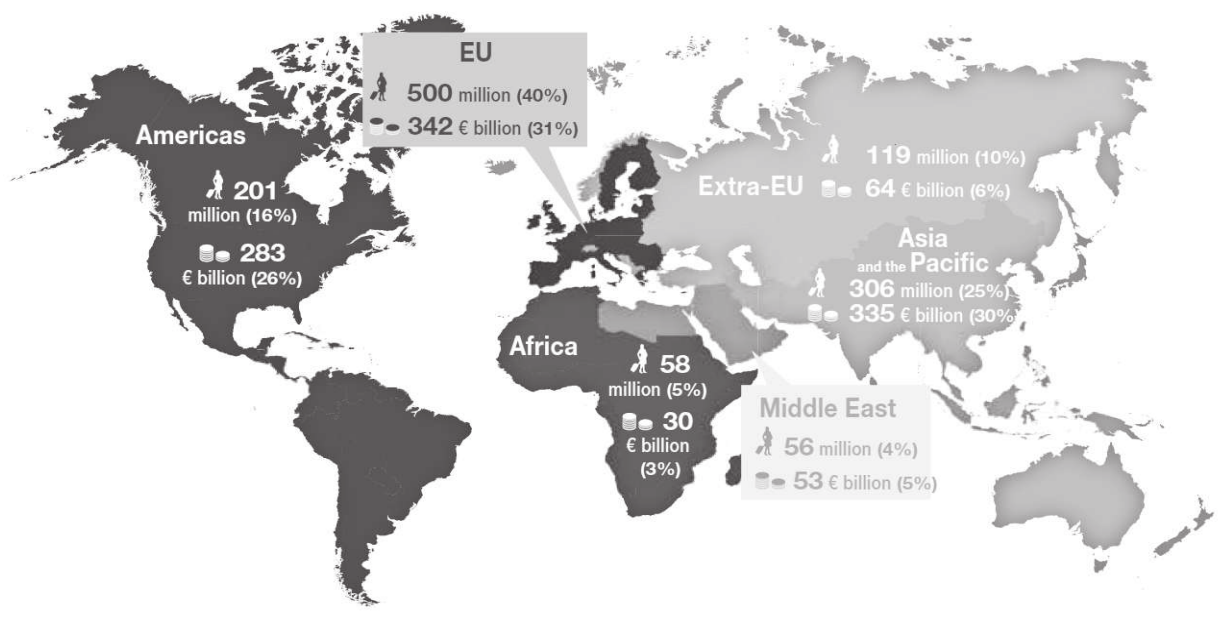

Rys. 1. Wpływy z turystyki międzynarodowej w roku 2016 (Euro)

Fig. 1. Proceeds from international tourism in 2016 (Euro)

Źródło: European Union Tourism Trends, UNWTO, Madrid 2018.

Rozwój turystyki w danym państwie znacząco przyczynia się do rozwoju przedsiębiorczości i infrastruktury. Przez wzrastający z roku na rok popyt na usługi turystyczne rozwój tej branży w sposób globalny oddziałuje na poziom przedsiębiorczości, inwestycji i innowacji. Rozwój przedsiębiorczości przez ilość odprowadzanych podatków stymuluje rozwój poszczególnych regionów oraz całego kraju. Przychody uzyskiwane z podatków pozwalają na realizację niezbędnych inwestycji turystycznych. To podnosi atrakcyjność danego państwa, które staje się znaną destynacją turystyczną (za Panasiuk, 2014).

Niedołączoną cechą branży turystycznej jest transfer środków pieniężnych ze stałego miejsca zamieszkania turystów do docelowych miejsc wypoczynku. Przybywając do obszarów recepcji turystycznej, turyści wprowadzają do obiegu określone środki pieniężne, które albo można zakumulować lub dalej wydatkować. Środki pieniężne pochodzące od turystów zamieniane są na towary i usługi, a następnie krążą w gospodarce, tworząc efekt finansowy we wszystkich fazach obrotu gospodarczego.

Na stan i tendencje rozwojowe turystyki duży wpływ mają zmiany w zglobalizowanej gospodarce światowej, takie jak:

- czynniki polityczne: utrzymywanie się w wielu regionach konfliktów o skali lokalnej i regionalnej, co wpływać będzie w sposób negatywny na rozmiary oraz kierunki ruchu turystycznego;

- czynniki gospodarcze: utrzymujący się kryzys w wielu rozwiniętych gospodarkach powodować będzie zmniejszanie się ruchu turystycznego do i z tych państw, przy jednoczesnym zwiększaniu się ruchu turystycznego do państw znajdujących się na ścieżce szybkiego rozwoju (kraje BRIC: Brazylia, Rosja, Indie, Chiny czy MIST: Meksyk, Indonezja, Korea Południowa i Turcja); 


\section{K. Eukasiewicz}

- czynniki społeczne: wzrost gospodarczy, wzrastający poziom edukacji oraz ogólny wzrost dobrobytu będą mieć wpływ zarówno na stronę podażową jak i popytową oferty turystycznej - będzie ona w większym stopniu uwzględniać bardziej wyrafinowane potrzeby turystów;

- czynniki środowiskowe: wzrastająca świadomość społeczna w odniesieniu do spraw związanych $\mathrm{z}$ ochroną środowiska i klimatu skutkować będzie zmianami w ofercie turystycznej w kierunku zapewnienia jak najwyższego poziomu ochrony środowiska naturalnego także w obszarze turystyki;

- czynniki technologiczne: rozwój technologii informacyjnych i komunikacyjnych wywiera olbrzymi wpływ na sposób świadczenia usług turystycznych, ale także na zwiększenie dostępności usług turystycznych $\mathrm{i}$ ich dopasowania do różnorodnych potrzeb konsumentów (Program, 2014).

\section{Dane i metody}

Do przeprowadzenia analizy wykorzystano dane pochodzące $\mathrm{z}$ opracowań Ministerstwa Sportu i Turystyki (w porozumieniu z Głównym Urzędem Statystycznym oraz Narodowym Bankiem Polskim) a także Polskiej Organizacji Turystycznej.

W wyniku prowadzonych analiz przedstawiono charakterystykę przyjazdów do Polski turystów zagranicznych wraz $\mathrm{z}$ ich wydatkami. Na potrzeby artykułu przedstawiono również analizę SWOT ukazującą mocne i słabe strony (czynniki wewnętrzne dla Polski) oraz szanse i zagrożenia, czyli czynniki zewnętrzne w stosunku do Polski. Przedstawiona analiza pozwoliła na określenie perspektyw rozwoju turystyki przyjazdowej do Polski.

\section{Wizerunek Polski}

Turystyka jest ważnym elementem budującym markę kraju. Polska jako marka istnieje, co nie dotyczy wszystkich krajów na świecie. Uznaje się że marka ta jest jeszcze rozmyta, mało wyrazista i jeszcze słaba. Wg Simona Anholta kraje dzielą się w percepcji świata na cztery kategorie (Anholt, 2007):

- Stare i nudne dla rynku nudne (np. Etiopia, Szwajcaria);

- Nowe i nudne - dla rynku dość nudne (np. Kanada, Polska);

- Stare i interesujące - dla rynku dość atrakcyjne (np. Chiny, Egipt);

- Nowe i interesujące - dla rynku bardzo interesujące (np. Nowa Zelandia, Islandia).

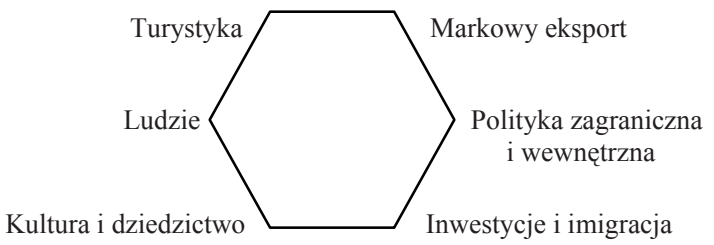

Rys. 2. Sześciokąt tożsamości konkurencyjnej

Fig. 2. The hexagon of competitive identity

Źródło: S. Anholt: Tożsamość konkurencyjna. Nowe spojrzenie na markę. Instytut Marki Polskiej Warszawa 2007, s. 40. 
Wśród przyjeżdżających turystów zagranicznych uchodzimy za gościnny, bezpieczny, nowoczesny kraj. Polska zachęca poprzez unikatowe walory naturalne: Bałtyk, pustynia Błędowska, mazurskie jeziora, Tatry, Bieszczady i wiele innych Warto zobaczyć Stare Miasto w Warszawie, czy Wrocławiu, rynek w Krakowie, Łazienki Królewskie, Kopalnię Soli w Wieliczce, zamek w Malborku, czy na Wawelu. To tylko niektóre atrakcje, ich lista jest długa. Stanowią one podstawę wizerunku naszego kraju.

\section{Charakterystyka przyjazdów do Polski}

W roku 2017 według szacunków Ministerstwa Sportu i Turystyki do Polski przyjechało 83804 nierezydentów, tj. o 13,6 \% więcej niż w 2014 roku. Liczbę turystów zagranicznych oszacowano na $18258 \mathrm{mln}$ (o 14,1\% więcej niż w 2014 roku). Dane przedstawiono w tabeli 1.

Tabela 1. Liczba przyjazdów do Polski w 2014 i 2017 roku wg głównych grup krajów i wybranych krajów* (w tys.)

Table 1. Number of arrivals to Poland in 2014 and 2017 by main groups of countries and selected countries * (in thousands)

\begin{tabular}{|c|c|c|c|c|c|c|}
\hline \multirow{2}{*}{ Kraj/grupa krajów } & \multicolumn{2}{|c|}{ Przyjazdy ogółem } & \multirow{2}{*}{$\begin{array}{c}\text { Zmiana } \\
2017 / 2014(\%)\end{array}$} & \multicolumn{2}{|c|}{ W tym turyści } & \multirow{2}{*}{$\begin{array}{c}\text { Zmiana } \\
2017 / 2014(\%)\end{array}$} \\
\hline & 2014 & 2017 & & 2014 & 2017 & \\
\hline Ogółem & 73750 & 83804 & 113,6 & 16000 & 18258 & 114,1 \\
\hline 27 krajów UE & 56013 & 63243 & 112,9 & 11379 & 13124 & 115,3 \\
\hline Stara UE & 34659 & 38897 & 112,2 & 9397 & 10929 & 116,3 \\
\hline Niemcy & 30260 & 33680 & 111,3 & 5743 & 6504 & 113,3 \\
\hline Wielka Brytania & 862 & 1056 & 122,5 & 664 & 851 & 128,2 \\
\hline Francja & 572 & 662 & 115,7 & 427 & 518 & 121,3 \\
\hline Włochy & 444 & 575 & 129,5 & 398 & 527 & 132,4 \\
\hline Niderlandy & 487 & 556 & 114,2 & 399 & 460 & 115,3 \\
\hline Austria & 432 & 469 & 108,6 & 355 & 389 & 109,6 \\
\hline Szwecja & 297 & 371 & 124,9 & 257 & 324 & 126,1 \\
\hline Pozostałe kraje 15UE & 1307 & 1528 & 116,9 & 1154 & 1358 & 117,7 \\
\hline Nowa UE & 21354 & 24346 & 114,0 & 1982 & 2195 & 110,7 \\
\hline Czeska Republika & 11374 & 12850 & 113,0 & 266 & 307 & 115,4 \\
\hline Słowacja & 5769 & 6704 & 116,2 & 159 & 188 & 118,2 \\
\hline Litwa & 2605 & 3113 & 119,5 & 605 & 677 & 111,9 \\
\hline Węgry & 257 & 293 & 114,0 & 208 & 237 & 113,9 \\
\hline Lotwa & 742 & 743 & 100,1 & 363 & 368 & 101,4 \\
\hline Pozostałe kraje 12UE & 607 & 642 & 105,8 & 381 & 416 & 109,2 \\
\hline Sąsiedzi spoza Schengen & 15605 & 18033 & 115,6 & 2888 & 2999 & 103,8 \\
\hline Ukraina & 8732 & 11744 & 134,5 & 1072 & 1359 & 126,8 \\
\hline Białoruś & 4066 & 4048 & 99,6 & 811 & 764 & 94,2 \\
\hline Rosja & 2807 & 2239 & 79,8 & 1003 & 876 & 87,3 \\
\hline Ważne zamorskie & 780 & 942 & 120,8 & 616 & 763 & 123,9 \\
\hline USA & 508 & 624 & 122,8 & 394 & 495 & 125,6 \\
\hline Pozostałe zamorskie** & 271 & 318 & 117,3 & 223 & 266 & 119,3 \\
\hline Reszta świata & 1352 & 1586 & 117,3 & 1117 & 1374 & 123,0 \\
\hline
\end{tabular}

*Zaprezentowana w tabeli typologię wg głównych grup krajów i wybranych krajów przyjęto wg opracowania Ministerstwa Sportu i Turystyki w porozumieniu z GUS oraz NBP. **Australia, Japonia, Kanada, Korea Płd.

Źródło: opracowanie własne na podstawie Charakterystyki przyjazdów nierezydentów do Polski w 2017 roku, Ministerstwo Sportu i Turystyki, Warszawa 2015, 2018 


\section{K. Lukasiewicz}

Zdecydowanie najwięcej przyjazdów zauważamy w przypadku mieszkańców Ukrainy. W porównaniu do roku 2014 w roku 2017 przyjechało ich do Polski o 34,5\%więcej. Kolejną liczną grupę stanowili Włosi oraz Szwedzi. Spadek liczby odwiedzających odnotowano w przypadku Rosjan (spadek o 0,4\%) i Białorusinów (spadek o 20,2\%).

Tabela 2. Cele przyjazdów turystów zagranicznych do Polski w 2014 i 2017 roku (\%)

Table 2. Goals of foreign tourists arriving to Poland in 2014 and 2017 (\%)

\begin{tabular}{l|ccccccccccccc}
\hline \multirow{2}{*}{$\begin{array}{l}\text { Główne cele } \\
\text { przyjazdów }\end{array}$} & \multicolumn{2}{|c}{ Ogółem } & \multicolumn{2}{c}{ Niemcy } & \multicolumn{2}{c}{ 14 UE } & \multicolumn{2}{c}{ Nowe kraje UE } & $\begin{array}{c}\text { Rosja Białoruś } \\
\text { Ukraina }\end{array}$ & $\begin{array}{c}\text { Główne } \\
\text { zamorskie }\end{array}$ \\
& 2014 & 2017 & 2014 & 2017 & 2014 & 2017 & 2014 & 2017 & 2014 & 2017 & 2014 & 2017 \\
\hline Służbowe & 28,7 & 24,8 & 12,5 & 10,2 & 22,8 & 21,2 & 54,9 & 47,0 & 49,8 & 39,3 & 20,9 & 21,5 \\
Turystyczne & 18,4 & 26,7 & 13,6 & 27,5 & 24,1 & 30,8 & 22,1 & 29,9 & 15,2 & 13,5 & 28,4 & 34,3 \\
Odwiedziny & 40,7 & 37,9 & 66,0 & 56,2 & 42,5 & 41,5 & 13,6 & 17,5 & 11,9 & 13,7 & 44,6 & 38,7 \\
Tranzyt & 2,1 & 2,0 & 1,6 & 0,8 & 1,6 & 0,5 & 2,7 & 1,5 & 4,3 & 8,2 & 0,8 & 0,3 \\
Zakupy & 4,4 & 4,4 & 1,8 & 1,2 & 0,6 & 0,7 & 3,5 & 1,5 & 16,8 & 22,3 & 0,0 & 0,0 \\
Inne cele & 5,8 & 4,1 & 4,6 & 4,0 & 8,3 & 5,3 & 3,2 & 2,7 & 2,0 & 2,9 & 5,1 & 5,2 \\
\hline
\end{tabular}

Źródło: opracowanie własne na podstawie Charakterystyki przyjazdów nierezydentów do Polski w 2017 roku, Ministerstwo Sportu i Turystyki, Warszawa 2015, 2018.

W tabeli 2 przedstawiono cele przyjazdów turystów zagranicznych do Polski. W przypadku przyjeżdżających z Niemiec liczba przyjazdów typowo turystycznych w roku 2017 wzrosła dwukrotnie. Liczba odwiedzin i przyjazdów służbowych nieznacznie zmalała. Inaczej przedstawia się sytuacja $\mathrm{w}$ przypadku przyjeżdżających $\mathrm{z}$ Rosji, Białorusi $\mathrm{i}$ Ukrainy. Liczba przyjazdów służbowych, turystycznych, odwiedzin nieznacznie zmalała. Wzrosło zaś zainteresowanie tej grupy odwiedzających dokonywaniem zakupów w naszym kraju. Liczba przyjeżdżających w celach zakupowych zwiększyła się w roku 2017 o 32,7\% w porównaniu do roku 2014. To oznacza, że w tej grupie możemy upatrywać szansy rozwoju turystyki w Polsce. Cel turystyczny, który z roku na rok odgrywa większe znaczenie można połączyć z celami zakupowymi.

Tabela 3. Długość pobytu turystów zagranicznych w Polsce w 2014 i 2017 roku (\%)

Table 3. Length of stay of foreign tourists in Poland in 2014 and 2017 (\%)

\begin{tabular}{|c|c|c|c|c|c|c|c|c|c|c|c|c|}
\hline \multirow[t]{2}{*}{$\begin{array}{c}\text { Długość } \\
\text { pobytu }\end{array}$} & \multicolumn{2}{|c|}{ Ogółem } & \multicolumn{2}{|c|}{ Niemcy } & \multicolumn{2}{|c|}{$14 \mathrm{UE}$} & \multicolumn{2}{|c|}{$\begin{array}{c}\text { Nowe kraje } \\
\text { UE }\end{array}$} & \multicolumn{2}{|c|}{$\begin{array}{l}\text { Rosja, } \\
\text { Białoruś } \\
\text { Ukraina }\end{array}$} & \multicolumn{2}{|c|}{$\begin{array}{c}\text { Główne } \\
\text { zamorskie }\end{array}$} \\
\hline & 2014 & 2017 & 2014 & 2017 & 2014 & 2017 & 2014 & 2017 & 2014 & 2017 & 2014 & 2017 \\
\hline $\begin{array}{l}1 \text { do } 3 \\
\text { noclegów }\end{array}$ & 55,9 & 44,9 & 42,3 & 33,9 & 44,3 & 30,2 & 90,8 & 70,6 & 88,1 & 88,0 & 20,4 & 10,6 \\
\hline $\begin{array}{l}4 \text { do } 7 \\
\text { noclegów }\end{array}$ & 31,1 & 32,4 & 45,0 & 44,0 & 38,5 & 41,9 & 6,3 & 18,4 & 8,1 & 8,3 & 22,9 & 27,3 \\
\hline $\begin{array}{l}8 \text { do } 28 \\
\text { noclegów }\end{array}$ & 11,6 & 21,0 & 12,2 & 21,2 & 16,1 & 26,3 & 2,7 & 10,5 & 3,3 & 2,9 & 45,5 & 50,4 \\
\hline Ponad 4 tyg. & 1,4 & 1,7 & 0,4 & 0,9 & 1,2 & 1,6 & 0,2 & 0,5 & 0,5 & 0,9 & 11,2 & 11,8 \\
\hline $\begin{array}{l}\text { Średnia liczba } \\
\text { noclegów }\end{array}$ & 5,1 & 6,2 & 5,1 & 5,9 & 5,5 & 7,5 & 2,1 & 3,9 & 2,5 & 2,5 & 15,8 & 15,1 \\
\hline
\end{tabular}

Źródło: opracowanie własne na podstawie Charakterystyki przyjazdów nierezydentów do Polski w 2017 roku, Ministerstwo Sportu i Turystyki, Warszawa 2015, 2018. 
W tabeli 3 przedstawiono długość pobytu turystów zagranicznych odwiedzających Polskę. Największą grupe stanowili przyjeżdżający na 1 do 3 dni, kolejna grupa to odwiedzający na 4 do 7 dni, a ostatnia to od 8 do 28 dni. Średnia długość pobytu zwiększyła się w 2017 roku o 21,6\% w stosunku do roku 2014.

W tabeli 4 możemy znaleźć informacje dotyczące wykorzystywanej podczas pobytu w Polsce bazy noclegowej. W roku 2017 w ogólnej liczbie przeważa korzystanie z noclegu u rodziny lub znajomych $(41,3 \%)$ oraz $w$ hotelach i motelach $(40,6 \%)$. Mniej turystów zagranicznych korzystało $\mathrm{z}$ noclegów $\mathrm{w}$ pensjonatach i kwaterach prywatnych (odpowiednio 3,9\% oraz 3,4\%)

Tabela 4. Wykorzystanie bazy noclegowej przez turystów zagranicznych przyjeżdżających do Polski w 2014 i 2017 roku (\%)

Table 4. Use of accommodation facilities by foreign tourists coming to Poland in 2014 and 2017 (\%)

\begin{tabular}{|c|c|c|c|c|c|c|c|c|c|c|c|c|}
\hline \multirow{2}{*}{$\begin{array}{c}\text { Miejsce } \\
\text { noclegowe }\end{array}$} & \multicolumn{2}{|c|}{ Ogółem } & \multicolumn{2}{|c|}{ Niemcy } & \multicolumn{2}{|c|}{$14 \mathrm{UE}$} & \multicolumn{2}{|c|}{ Nowe kraje UE } & \multicolumn{2}{|c|}{$\begin{array}{c}\text { Rosja Białoruś } \\
\text { Ukraina }\end{array}$} & \multicolumn{2}{|c|}{$\begin{array}{c}\text { Główne } \\
\text { zamorskie }\end{array}$} \\
\hline & 2014 & 2017 & 2014 & 2017 & 2014 & 2017 & 2014 & 2017 & 2014 & 2017 & 2014 & 2017 \\
\hline $\begin{array}{l}\text { Hotele, } \\
\text { motele }\end{array}$ & 27,9 & 40,6 & 17,0 & 33,1 & 37,9 & 46,6 & 23,5 & 43,2 & 25,8 & 38,1 & 50,6 & 64,1 \\
\hline $\begin{array}{l}\text { U rodziny } \\
\text { lub } \\
\text { znajomych }\end{array}$ & 46,5 & 41,3 & 74,5 & 56,5 & 47,3 & 46,9 & 17,6 & 20,1 & 15,6 & 21,9 & 46,6 & 34,2 \\
\hline Pensjonaty & 3,8 & 3,9 & 3,8 & 4,2 & 5,6 & 3,8 & 1,1 & 2,5 & 3,8 & 5,5 & 1,4 & 2,4 \\
\hline $\begin{array}{l}\text { Kwatery } \\
\text { prywatne }\end{array}$ & 2,5 & 3,4 & 1,0 & 3,6 & 2,4 & 2,0 & 5,2 & 3,8 & 4,2 & 5,1 & 3,4 & 2,2 \\
\hline Inne & 20,5 & 12,7 & 4,2 & 3,8 & 8,5 & 4,4 & 52,7 & 31,1 & 52,7 & 30,1 & 1,9 & 3,0 \\
\hline
\end{tabular}

Źródło: opracowanie własne na podstawie Charakterystyki przyjazdów nierezydentów do Polski w 2017 roku, Ministerstwo Sportu i Turystyki, Warszawa 2015, 2018.

Inaczej przedstawiała się sytuacja $\mathrm{w}$ przypadku turystów zagranicznych $\mathrm{z}$ Rosji, Białorusi i Ukrainy. Wykorzystywali oni najczęściej nocleg w hotelach i motelach $(38,1 \%)$ oraz u rodziny i znajomych $(21,9 \%)$.

\section{Wielkość i struktura wydatków turystów zagranicznych w Polsce}

Analizując dane zebrane w roku 2017 roku można zauważyć, że przeciętne wydatki turystów zagranicznych poniesione na terenie Polski ukształtowały się na poziomie 455 USD na osobę w roku 2014, a 476 USD na osobę w roku 2017 (więcej o 4,6\%). Najwyższe wydatki dotyczyły krajów Skandynawskich oraz Niemiec. 


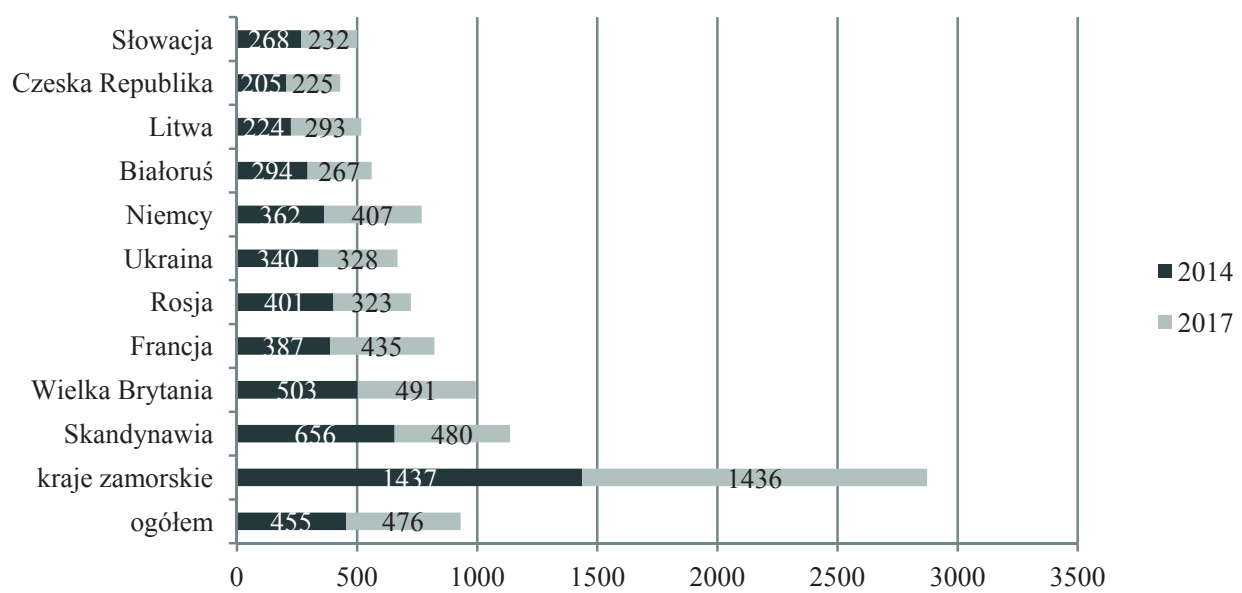

Rys. 3. Przeciętne wydatki turystów zagranicznych na osobę w 2014 i 2017r. w USD (według krajów)

Fig. 3. Average expenses of foreign tourists per person in 2014 and 2017. in USD (by country)

Źródło: opracowanie własne na podstawie Charakterystyki przyjazdów nierezydentów do Polski w 2017 roku, Ministerstwo Sportu i Turystyki, Warszawa 2015, 2018.

Można zauważyć znaczny stopień zróżnicowania przeciętnych wydatków według krajów: wydatki te wahały się w roku 2017 w granicach od 225 USD (Czeska Republika) przez 407 USD (Niemcy), 480 USD (Skandynawia) aż do 1436 USD (Kraje zamorskie). W stosunku do roku 2014, w roku 2017 wzrost wielkości przeciętnych wydatków na osobę zanotowano głównie z Niemiec, Francji, Litwy, Czeskiej Republiki. Zaobserwować można spadek wydatków cudzoziemców ze Skandynawii, z Rosji, z Ukrainy.

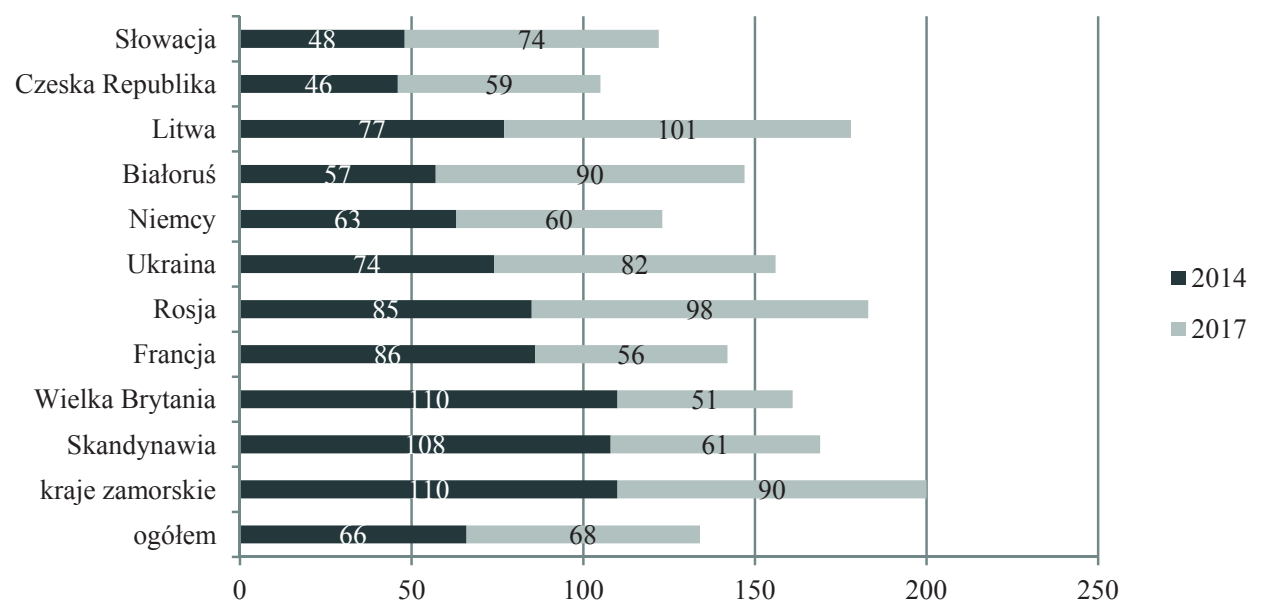

Rys. 4. Przeciętne wydatki turystów na 1 dzień pobytu w 2014 i w 2017 roku w USD (według krajów)

Fig. 2. Average tourist expenses for one day of stay in 2014 and 2017 in USD (by country)

Źródło: opracowanie własne na podstawie Charakterystyki przyjazdów nierezydentów do Polski w 2017 roku, Ministerstwo Sportu i Turystyki, Warszawa 2015, 2018. 
Przyjazdy cudzoziemców do Polski wywołują różne konsekwencje dla kraju odwiedzanego. Można te konsekwencje rozpatrywać od strony ekonomicznej, logistycznej, społeczno-kulturowej, ekologicznej, a także częściowo demograficznej, politycznej, estetycznej, psychologicznej (Rakowski, Teperek, 2009).

W artykule zwrócono uwagę głównie na konsekwencje ekonomiczne. Przekraczanie granicy wymaga obsługi ruchu granicznego na różnych szczeblach organizacji danego państwa (ambasady, konsulaty, biura paszportowe, biura turystyczne, rozwija się handel, hotele, przewodnicy). Aby te elementy były spełnione potrzebne jest dokształcanie $\mathrm{w}$ różnym zakresie, ludzie szukają nowych źródeł aktywności w związku z czym spada bezrobocie. Kolejny element, który się pojawia to tworzenie infrastruktury w szerokim tego słowa znaczeniu (drogi, autostrady itp.) oraz budowa przejść na granicach do obsługi ruchu granicznego. Tym, którzy podróżują trzeba zapewnić nocleg wraz z wyżywieniem oraz wypoczynkiem. Powstaja zatem hotele, restauracje, baseny, SPA. Pojawiające się inwestycje powodują ożywienie gospodarcze, pojawia się popyt na pieniądz.

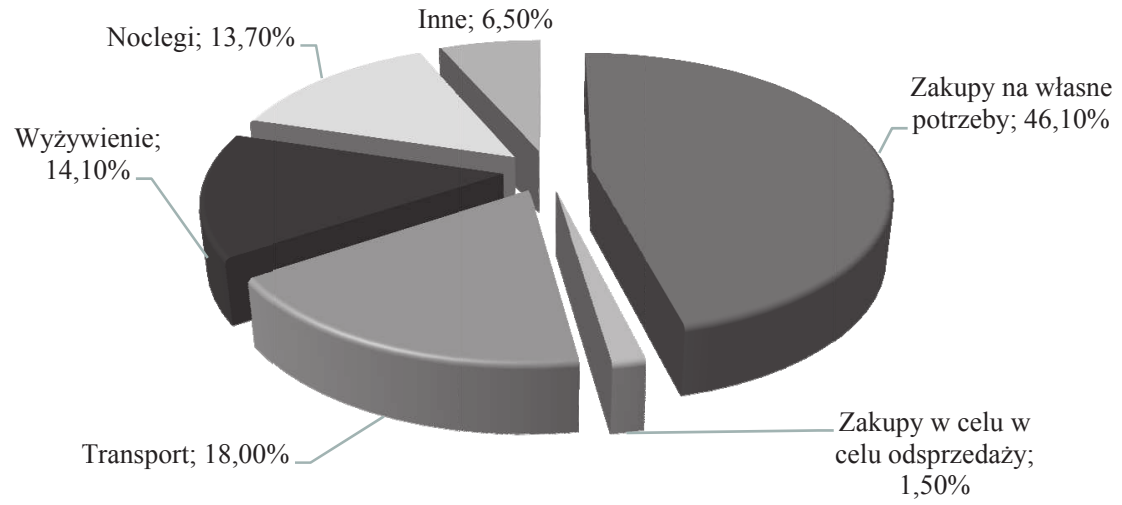

Rys. 5. Struktura wydatków poniesionych przez turystów zagranicznych na terenie Polski w 2017 roku (\%)

Fig. 5. Structure of expenses incurred by foreign tourists in Poland in 2017 (\%)

Źródło: Charakterystyka przyjazdów nierezydentów do Polski w 2017 roku, Ministerstwo Sportu i Turystyki, Warszawa 2018

$\mathrm{Na}$ rys. 5 zaprezentowano strukturę wydatków poniesionych przez turystów zagranicznych w Polsce. Główna grupa wydatków to te poniesione na zakupy na własne potrzeby $(46,10 \%)$, transport $(18,00 \%)$, wyżywienie $(14,10 \%)$, czy noclegi $(13,7 \%)$. Struktura tych wydatków w stosunku do roku 2014 nie zmieniła się.

\section{Analiza SWOT}

Poniżej przedstawiono analizę SWOT zagranicznej turystyki przyjazdowej. Wśród analizowanych czynników przeważają mocne strony takie jak m.in.: centralne położenie w Europie, wyjątkowe walory naturalne, szeroka oferta produktów turystycznych, czy wreszcie coraz wyższa jakość obsługi. Na uwagę zasługują również szanse jakie pojawiają 


\section{K. Eukasiewicz}

się w otoczeniu. Zaliczyć można do nich m.in.: pozytywne wrażenia wracających z Polski, pozytywny efekt wizerunkowy związany z odbytymi wydarzeniami, czy wykorzystanie marek poszczególnych miast (Warszawa, Kraków, Wrocław, Gdańsk).

Tabela 5. Analiza SWOT turystyki zagranicznej przyjazdowej

Table 5. SWOT analysis of incoming foreign tourism

\begin{tabular}{|c|c|}
\hline Mocne strony & Słabe strony \\
\hline Stan bazy noclegowej (nowoczesne obiekty) & Słaba rozpoznawalność marki POLSKA \\
\hline Centralne położenie w Europie & Brak analiz dotyczących potrzeb \\
\hline Obszary o korzystnych, wyjatkowych walorach & zagranicznych \\
\hline naturalnych & Nadal słabe wskaźniki stanu bazy noclegowej \\
\hline Bliskość wybrzeża bałtyckiego & Brak wsparcia ze strony podmiotów spoza branży \\
\hline Ogromna różnorodność dziedzictwa & turystycznej \\
\hline kulturowego & Brak tworzonych z dużym wyprzedzeniem kalendarzy \\
\hline Szeroka oferta produktów turystycznych & imprez sportowych czy kulinarnych \\
\hline Kuchnia regionalna/zdrowa żywność & Infrastruktura drogowa, kolejowa, rowerowa \\
\hline \multicolumn{2}{|l|}{ Gościnność } \\
\hline \multicolumn{2}{|l|}{$\begin{array}{l}\text { Coraz lepszy stan infrastruktury/komunikacji lotniczej } \\
\text { i lądowej }\end{array}$} \\
\hline Duża różnorodność rodzajów turystyki & \\
\hline Coraz wyższa jakość obsługi & \\
\hline
\end{tabular}

\begin{tabular}{|c|c|}
\hline Szanse & Zagrożenia \\
\hline $\begin{array}{l}\text { Pozytywne wrażenia i rekomendacje wracających } \\
\text { z Polski }\end{array}$ & $\begin{array}{l}\text { Wzrost cen/niekorzystne kursy walut } \\
\text { Brak stabilności tanich linii lotniczych }\end{array}$ \\
\hline Pozytywny efekt wizerunkowy (np. EURO 2012) & Wysokie koszty transportu \\
\hline Wspieranie przez UE promocji Europy w tym Polski & Oczekiwanie niskiej ceny \\
\hline $\begin{array}{l}\text { Wzrost zainteresowania turystyką do Europy wśród } \\
\text { mieszkańców innych regionów świata }\end{array}$ & $\begin{array}{l}\text { Zmniejszone wydatki samorządów terytorialnych na } \\
\text { promocję turystyki }\end{array}$ \\
\hline Rozwój infrastruktury (drogowej, konferencyjnej) & Pogorszenie się koniunktury gospodarczej w Europie i \\
\hline $\begin{array}{l}\text { Rosnąca aktywność mieszkańców państw } \\
\text { sąsiadujących z Polską }\end{array}$ & na świecie \\
\hline $\begin{array}{l}\text { Wykorzystanie marek poszczególnych miast, które } \\
\text { przyciągają turystów z zagranicy (Warszawa, Kraków, } \\
\text { Gdańsk, Wrocław) }\end{array}$ & \\
\hline
\end{tabular}

Źródło: Marketingowa strategia Polski w sektorze turystyki na lata 2012-2020, Polska Organizacja Turystyczna, Warszawa 2011, s.72.

Warto zwrócić uwagę, iż słabych stron nie jest wiele. Wśród nich możemy odnotować m.in.: brak analiz dotyczących potrzeb turystów zagranicznych, nadal słaba rozpoznawalność marki POLSKA, brak tworzonych kalendarzy imprez odbywających się w kraju, które mogłyby przyczynić się do przyciagnięcia turystów do Polski. Znajdujemy też zagrożenia, jak choćby wzrost cen, czy pogorszenie się koniunktury gospodarczej w Europie i na świecie. 


\section{Podsumowanie}

W artykule zaprezentowano charakterystykę przyjazdów do Polski turystów zagranicznych z uwzględnieniem ich wydatków. W wyniku przeprowadzonej analizy stwierdzono, że:

- W 2017 r. liczba przyjazdów nierezydentów do Polski została oszacowana na poziomie 83,8 mln więcej niż w roku 2014, w tym liczbę turystów zagranicznych oszacowano na poziomie 18,3 mln (więcej o 14,1\% niż w 2014 r.) i w poprzednich latach;

- Głównym celem przyjazdu turystów zagranicznych do Polski były odwiedziny u krewnych i znajomych $(37,9 \%)$, cele turystyczne $(26,7 \%)$ oraz służbowe $(24,8 \%)$; mniejsze znaczenie miały zakupy $(4,4 \%)$;

- Najwięcej turystów zagranicznych korzystało w Polsce od 1 do 3 noclegów (44,9\%), od 4 do 7 noclegów oraz od 8 do 28 noclegów (21\%), wartości te nie różniły się znacząco od tych z roku 2014;

- Turyści zagraniczni przebywający w Polsce najczęściej wykorzystywali noclegi u rodziny $i$ znajomych $(41,3 \%)$ oraz $w$ hotelach i motelach $(40,6 \%)$; mniej w pensjonatach i kwaterach prywatnych (odpowiednio 3,9\% oraz 3,4\%). Nieco inaczej przedstawiała się sytuacja $\mathrm{w}$ przypadku turystów zagranicznych $\mathrm{z}$ Rosji, Białorusi i Ukrainy: najwięcej z nich korzystało z noclegów w hotelach i motelach $(38,1 \%)$;

- Przeciętne wydatki turystów poniesione na terenie Polski ukształtowały się na poziomie 476 USD na osobę (więcej niż w roku 2014). Najwięcej pozostawiały w Polsce turyści z krajów zamorskich (1 436 USD).

Do głównych perspektyw rozwoju turystyki przyjazdowej do Polski zaliczyć można: - ciaggle rosnącą liczbę przyjazdów turystów zagranicznych do Polski, która powinna się utrzymywać;

- rozwój różnych form i rodzajów turystyki dla osób w różnym wieku i o różnych zainteresowaniach;

- dbałość o poprawę infrastruktury oraz dostępność komunikacyjną;

-wzrost zainteresowania jakością usług, a w szczególności jakością usług specjalistycznych przy zdecydowanej poprawie i ujednoliceniu jakości usług standardowych;

- wzrost wydatków na cele kulturalno-rekreacyjne, a nie tylko na transport i nocleg;

- konkurencyjność polskich produktów turystycznych na rynku międzynarodowym i wysoką jakość kadr turystycznych

Turystyka jest ważną częścią gospodarki Polski. Gospodarka turystyczna w znacznym stopniu może przyczynić się do poprawy spójności gospodarczej, terytorialnej i społecznej Polski. Rozwój zrównoważony sektora turystyki wysokiej jakości stanowi jeden z kierunkowych priorytetów rozwojowych Unii Europejskiej. Rodzi to wyzwanie wzmocnienia potencjału gospodarczego i społecznego, sprzyjającego wzrostowi sektora turystyki, rozumianego jako element konkurencyjności gospodarczej regionów europejskich. Turystyka jest czynnikiem dywersyfikacji gospodarki, wywołującym zapotrzebowanie na wykwalifikowane kadry, innowacyjne usługi i nowoczesne narzędzia zarządzania oraz badania i analizy wspierające zrównoważony rozwój gospodarczy oparty na turystyce. Wszystko to stwarza nowe możliwości ujęcia rozwoju turystyki, jako części polityki regionalnej, wzmacniającej konkurencyjność danego terytorium. 


\section{K. Eukasiewicz}

\section{Literatura}

Anholt, S. (2007). Tożsamość konkurencyjna. Nowe spojrzenie na markę (Competitive identity. A new look at the brand). Instytut Marki Polskiej, Warszawa.

Balińska, A., Sieczko, A., Zawadka, J. (2014). Turystyka. Wybrane zagadnienia (Tourism. Selected issues). Difin, Warszawa.

Charakterystyka przyjazdów nierezydentów do Polski w 2014 roku (Characteristic of arrivals of non-residents to Poland in 2014). (2015). MSiT, Warszawa.

Charakterystyka przyjazdów nierezydentów do Polski w 2017 roku (Characteristic of arrivals of non-residents to Poland in 2017). (2018). MSiT, Warszawa.

Dąbrowska, B. (2011). Turystyka międzynarodowa w globalnej gospodarce (International tourism in the global economy). PWE Warszawa.

European Union Tourism Trends. UNWTO, Madrid 2018.

Gaworecki, W. (2013). Turystyka (Tourism). PWE Warszawa.

Marketingowa strategia Polski w sektorze turystyki na lata 2012-2020 (Polish marketing strategy in the tourism sector for years). (2011). POT, Warszawa.

Panasiuk, A. (2014). Rynek turystyczny. Studium strukturalne (Tourist market. Structural study). Difin, Warszawa.

Program rozwoju turystyki do 2020 roku (Tourism development program until 2020). (2014). Ministerstwo Sportu i Turystyki Warszawa (projekt PDF).

Rakowski, W. Teperek, A. (2009). Wyjazdy Polaków za granicę i przyjazdy cudzoziemców do Polski w latach 2001-2008 (Poles' trias abroad and arrivals of foreigners to Poland in the years). Rocznik Żyrardowski 7, 243-264.

Do cytowania / For citation:

Łukasiewicz K. (2018). Przyjazdy turystów zagranicznych do Polski oraz ich wydatki w latach 2014-2017 - charakterystyka i perspektywy rozwoju. Problemy Rolnictwa Światowego, 18(4), 333-344; DOI: 10.22630/PRS.2018.18.4.123

Łukasiewicz K. (2018). Arrivals of Foreign Tourists to Poland and Their Expenses in 2014-2017; Characteristics and Development Perspectives (in Polish). Problems of World Agriculture, 18(4), 333-344; DOI: 10.22630/PRS.2018.18.4.123 